\title{
APLIKASI KOMPOS DAN PENAMBAHAN BAHAN ORGANIK TERHADAP PERTUMBUHAN DAN HASIL SELADA PADA ULTISOL
}

\author{
The Application of Compost and Addition of Organic Matter on Lettuce Growth and Yield \\ in Ultisols
}

\author{
Wahyu Febriyono* dan Affiatin Rahmah \\ Program Studi Agribisnis, Fakultas Sains dan Teknologi, Universitas Peradaban, \\ Jl. Raya Pagojengan, Paguyangan, Kab. Brebes, Jawa Tengah \\ *Alamat korespondensi: wahyufebriyono@gmail.com
}

\begin{abstract}
ABSTRAK
Gulma siam memiliki potensi untuk dijadikan pupuk kompos yang dapat digunakan untuk meningkatkan produksi tanaman selada di ultisol. Penelitian ini bertujuan untuk mengetahui pengaruh penggunaan kompos gulma siam dan kompos komersial dengan penambahan bahan organik dengan kadar berbeda pada ultisol terhadap pertumbuhan dan hasil selada pada ultisol. Penelitian ini menggunakan rancangan acak kelompok faktorial. Faktor pertama adalah kompos gulma siam dan kompos komersial, dan faktor kedua adalah penambahan bahan organik dengan kadar berbeda yaitu 0\%, $1 \%, 2 \%$ dan 3\%. Variabel yang diamati antara lain tinggi tanaman, jumlah daun, bobot tanaman segar, bobot tanaman kering, bobot akar segar, bobot akar kering, total panjang akar, luas daun, laju asimilasi bersih dan laju pertumbuhan tanaman. Hasil penelitian diketahui bahwa tanaman selada dengan kompos gulma siam dapat tumbuh dengan baik didukung oleh variabel tinggi tanaman (27,1 g), bobot tanaman segar $(30,57 \mathrm{~g})$, bobot akar kering $(0,08 \mathrm{~g})$, dan luas daun $\left(811,77 \mathrm{~cm}^{2}\right)$. Aplikasi kompos dan pupuk organik dengan penambahan bahan organik 2-3\% mampu meningkatkan hasil segar selada pada ultisol.
\end{abstract}

Kata kunci: kompos gulma siam, selada, ultisol

\begin{abstract}
Siam weed has the potential to be used as compost, which can be used to increase the production of lettuce in ultisol. This study aimed to know the application of siam weed compost dan commercial compost along with addition of different dose of organic matter in ultisol on growth and yield of lettuce. This study used a factorial complete randomized block design. The first factor was siam weed compost and commercial compost, and the second factor was the percentage addition of organic matter viz. 0, 1, 2, and 3. The variables observed were plant height, number of leaves, fresh plant weight, dry plant weight, fresh root weight, dry root weight, total root length, leaf area, net assimilation rate, and plant growth rate. The results showed that lettuce with Siamese weed compost could grow well supported by the variable plant height (27.1 g), fresh plant weight (30.57 g), dry root weight $(0.08$ $\mathrm{g})$, and leaf area. (811.77 cm2). Applications of compost along with additon of 2-3\% organic matter improved lettuce fresh yield in ultisol.
\end{abstract}

Keywords: lettuce, siam weeds compost, ultisols

\section{PENDAHULUAN}

Gulma siam (Chromolaena odorata

(L.) King \& Robins) berasal dari Amerika tengah dan Amerika selatan, masuk ke Indonesia melalui Thailand. Di Indonesia gulma siam terbukti dapat tumbuh di berbagai tempat, tetapi populasi terbanyak berada pada daerah lahan kosong (Suharjo \& Aeny, 2011). Secara kuantitatif gulma siam mampu menghasilkan biomassa yang sangat tinggi mencapai 80 ton biomassa segar per hektar pada kerapatan mencapai 24-37 individu $\mathrm{m}^{2}$. Secara kualitatif gulma siam mengandung unsur hara yang tinggi yaitu masing- masing 2,6 \% N; 0,38 \% P; dan $2,41 \% \mathrm{~K}$ dengan rasio $\mathrm{C} / \mathrm{N}$ di bawah titik kritis sehingga mudah dan cepat termineralisasi (Nugroho et al., 2019). 
Secara sederhana pengertian pengomposan adalah proses penguraian materi organik yang kompleks secara biologis oleh konsorsium mikroorganisme dengan menghasilkan materi organik yang sederhana dan relatif stabil menyerupai humus dalam kondisi yang terkendali (Sahwan, 2010). Hartini (2020), menyatakan bahwa pemberian kompos gulma siam dapat meningkatkan bobot basah tajuk, bobot kering tajuk dan meningkatkan pengkolonian mikoriza pada pembibitan kakao.

Selada (Lactuca sativa L.) merupakan sayuran daun yang berumur pendek dan dapat ditanam di dataran tinggi atau dataran rendah. Kandungan gizi selada terdiri dari protein, lemak, karbohidrat, $\mathrm{Ca}, \mathrm{P}, \mathrm{Fe}$, vitamin $\mathrm{A}$, vitamin $\mathrm{B}$, dan vitamin $\mathrm{C}$ (Fauzi et al., 2013). Usaha peningkatan produksi selada untuk memenuhi kebutuhan masyarakat diantaranya dengan perluasan lahan penanaman. Lahan ultisol merupakan lahan yang potensial untuk perluasan penanaman sayuran karena luasannya yang cukup luas dan belum banyak termanfaatkan. Upaya perluasan penanaman selada pada ultisol terkendala kesuburan tanah tersebut. Pertumbuhan dan hasil selada dapat ditingkatkan dengan aplikasi biochar yang dikombinasikan dengan kompos (Berek et al., 2017).

Ultisol mempunyai potensi keracunan Al dan miskin kadar bahan organik. Tanah ultisol memiliki $\mathrm{pH}$ antara 4,3-4,9, C organnik antara $0,2-1,1 \%, \mathrm{~N}$ total antara 0,09-0,18 \%, P total 0,048-0,053\%, P tersedia 0,53-2,00 ppm, K-dd 0,03-0,32 me/100 g, KTK 2,43-16,76 \%, kejenuhan basa $5,28-31,12 \%, \quad$ Al-dd $0,55-4,72$ me/100 g, dan kejenuhan Al 11,43-75,64 (Syahputra et al., 2015). Rendahnya kadar bahan organik akan mengakibatkan buruknya kondisi tanah yang seterusnya menjadikan pertumbuhan dan hasil tanamanpun ikut memburuk. Kendala tersebut dapat diatasi dengan menggunakan bahan organik (Sujana \& Pura, 2015).

Penelitian ini bertujuan untuk mengetahui pengaruh penggunaan kompos gulma siam dan kompos komersial dengan dengan penambahan bahan organik dengan kadar berbeda pada ultisol terhadap pertumbuhan dan hasil selada pada ultisol.

\section{METODE PENELITIAN}

Penelitian dilaksanakan pada bulan Oktober-Desember 2020. Bertempat di green house milik Program Studi Agribisnis Fakultas Sains dan Teknologi Universitas Peradaban. Rancangan yang digunakan adalah rancangan acak kelompok dengan pertimbangan faktor cahaya matahari yang kurang merata. Penelitian ini menggunakan dua faktor. Faktor yang pertama adalah jenis kompos terdiri atas kompos gulma siam dan kompos komersial. Faktor kedua 
adalah penambahan bahan organik $0 \%, 1 \%$ $2 \%$ dan $3 \%$.

Gulma siam yang diperoleh dari wilayah Bumiayu dan sekitarnya dicacah dengan ukuran 1-2 cm. Kemudian dibungkus dengan plastik agar terdekomposisi dengan baik. Pengomposan gulma siam berlangsung secara alami tanpa penambahan dekomposer selama 35 hari. Kompos gulma siam asal Bumiayu mengandung C organik 56,16\%, N 1,07\%, $\mathrm{P} 1,07 \%, \mathrm{~K} 2,74 \%, \mathrm{Mg} 0,50 \%, \mathrm{C} / \mathrm{N} 52,48$, KTK 53,97 me/100g, pH 7,5 dan kadar air $52,8 \%$. Ultisol berasal dari Desa Tanggeran, Kecamatan Somagede, Kabupaten Banyumas memiliki pH 4,72, C organik 0,87\%, P-jerapan $70 \%, \mathrm{~K}$-dd 0,11 cmol (+)/kg, Ca-dd 0,88 cmol (+)/kg, Mgdd 0,65 cmol (+)/kg, Al-dd 1,51 cmol $(+) / \mathrm{kg}, \mathrm{KTK} 11,80 \mathrm{cmol}(+) / \mathrm{kg}$ (Ismangil, 2009). Tanah yang telah halus diayak dengan ayakan berukuran $0,5 \mathrm{~cm}$. Tanah ditimbang seberat $6 \mathrm{~kg}$, kemudian dimasukkan ke dalam polybag dengan diameter $20 \mathrm{~cm}$.

Benih tanaman selada disemai dengan tanah berpasir. Benih dipindahkan ke media setelah mencapai ketinggian $5 \mathrm{~cm}$ dan memiliki 4 daun. Tanaman disiram setiap hari dan dilakukan penyiangan seminggu sekali. Pengamatan pertumbuhan dilakukan saat umur tanaman 28 hst antara lain pada: 1. Tinggi tanaman
Pengamatan tinggi tanaman diamati dengan mengukur tinggi tanaman dari pangkal sampai ujung. Pengamatan menggunakan penggaris.

2. Jumlah daun

Jumlah daun diamati dengan cara menghitung jumlah daun yang telah terbuka.

3. Luas daun

Luas daun diukur dengan menggunakan metode kertas millimeter. Sampel daun digambar di atas kertas millimeter dengan mengikuti pola daun tersebut.

4. Bobot tanaman segar

Bobot tanaman segar diamati dengan menimbang bagian tanaman yang ada di atas tanah ketika panen.

5. Bobot tanaman kering

Setelah bobot segar diketahui, tanaman dikering anginkan kemudian dioven dengan suhu $60{ }^{\circ} \mathrm{C}$ hingga bobotnya konstan.

6. Bobot akar segar

Pengamatan dilakukan setelah panen, dengan cara mencuci akar untuk membersihkan akar dari tanah, kemudian dikering anginkan dengan cara meletakkan akar pada kertas koran dan setelah kering akar ditimbang.

7. Bobot akar kering Pengamatan dilakukan setelah panen, akar dikeringkan terlebih dahulu dalam oven pada suhu $60{ }^{\circ} \mathrm{C}$ sampai bobot 
konstan kemudian ditimbang, satuannya berupa gram.

8. Total panjang akar

Total panjang akar diamati dengan cara mengukur panjang masing-masing akar pada millimeter blok kemudian seluruhnya dijumlahkan.

9. Laju Asimilasi Bersih $\left(\mathrm{g} / \mathrm{cm}^{2} /\right.$ hari)

Laju asimilasi bersih adalah laju penimbunan berat kering per satuan luas daun per satuan waktu dari sampel tanaman umur 7 dan 28 hst. LAB merupakan ukuran rata-rata efisiensi fotosintesis daun dalam suatu komunitas tanaman budidaya. LAB paling tinggi nilainya pada saat tumbuhan masih kecil dan sebagian besar daunnya terkena sinar matahari langsung. Tanaman yang terus tumbuh dan meningkatnya LAI, makin banyak daun terlindung, menyebabkan penurunan LAB sepanjang musim pertumbuhan. Laju asimilasi bersih merupakan ukuran rata-rata efisiensi fotosintesis daun dalam suatu komunitas tanaman budidaya. LAB dihitung pada akhir pengamatan.

$$
L A B=\frac{(W 2-W 1)}{(T 2-T 1)} X \frac{(\ln L A-2-\ln L A 1)}{(L A 2-L A 1)}
$$

Keterangan:

$\mathrm{W}=$ bobot kering tanaman

$\mathrm{T}=$ waktu

$\mathrm{LA}=$ luas daun tanaman

(Sitompul \& Guritno, 1995)
10. Laju Pertumbuhan Tanaman (LPT) $\left(\mathrm{g} / \mathrm{m}^{2} / \mathrm{hari}\right)$

Laju pertumbuhan tanaman adalah kemampuan tanaman menghasilkan bahan kering hasil asimilasi tiap satuan luas lahan tiap satuan waktu dari sampel tanaman umur 7 dan 28 hst. LPT dihitung pada akhir pengamatan.

$$
L P T=\frac{1}{G A} X \frac{(W 2-W 1)}{(T 2-T 1)}
$$

Keterangan:

$\mathrm{W}=$ bobot kering tanaman

$\mathrm{T}=$ waktu

$\mathrm{GA}=$ luas tanah

(Sitompul \& Guritno, 1995)

Data yang diperoleh dianalisis dengan uji $\mathrm{F}$ dengan taraf kepercayaan $95 \%$. Apabila menunjukkan perbedaan yang nyata dilanjutkan dengan uji Duncan Mutiple Range Test (DMRT) pada $p=0,05$

\section{HASIL DAN PEMBAHASAN}

Hasil penelitian secara umum terlihat pada Tabel 1. dimana perlakuan tunggal memberikan pengaruh yang sangat nyata pada variabel tinggi tanaman, jumlah daun, bobot tanaman segar, bobot tanaman kering, bobot akar segar, bobot akar kering, total panjang akar, luas daun, dan laju pertumbuhan tanaman. Sedangkan interaksi dari perlakuan menunjukkan perbedaan yang nyata pada variabel tinggi tanaman, bobot tanaman segar, bobot akar kering, dan luas daun. 
Tabel 1. Hasil sidik ragam pengaruh aplikasi kompos dan penambahan bahan organik terhadap pertumbuhan dan hasil selada pada ultisol.

\begin{tabular}{lccc}
\hline \multicolumn{1}{c}{ Variabel } & Pupuk kompos $(\mathrm{P})$ & Dosis $(\mathrm{D})$ & PxD \\
\hline Tingi tanaman $(\mathrm{cm})$ & $* *$ & $* *$ & $*$ \\
Jumlah taun (helai/tanaman) & $* *$ & $* *$ & - \\
Bobot tanaman segar $(\mathrm{g})$ & $* *$ & $* *$ & $*$ \\
Bobot tanaman kering $(\mathrm{g})$ & $* *$ & $* *$ & - \\
Bobot akar segar $(\mathrm{g})$ & $* *$ & $* *$ & - \\
Bobot akar kering $(\mathrm{g})$ & $* *$ & $* *$ & $*$ \\
Total panjang akar $(\mathrm{cm})$ & $* *$ & $* *$ & - \\
Luas daun $\left(\mathrm{cm}^{2}\right)$ & $* *$ & $* *$ & $*$ \\
Laju asimilasi bersih $\left(\mathrm{g} / \mathrm{cm}^{2} / \mathrm{hari}\right)$ & - & $*$ & - \\
Laju pertumbuhan tanaman $\left(\mathrm{g} / \mathrm{m}^{2} / \mathrm{hari}\right)$ & $* *$ & $* *$ & - \\
\hline Keter
\end{tabular}

Keterangan: $*=$ menunjukkan perbedaan yang nyata pada taraf kepercayaan $95 \%$, ** = menunjukkan perbedaan yang nyata pada taraf kepercayaan $99 \%,(-)=$ tidak menunjukkan perbedaan yang nyata pada tingkat kepercayaan $95 \%$.

Tabel 2. Tinggi tanaman selada pada masing masing perlakuan

\begin{tabular}{cc}
\hline Perlakuan & Tinggi tanaman $(\mathrm{cm})$ \\
\hline P1D0 & $17,80 \mathrm{ab}$ \\
P1D1 & $25,10 \mathrm{~b}$ \\
P1D2 & $27,10 \mathrm{~b}$ \\
P1D3 & $26,50 \mathrm{~b}$ \\
P2D0 & $17,10 \mathrm{a}$ \\
P2D1 & $20,60 \mathrm{~b}$ \\
P2D2 & $21,70 \mathrm{~b}$ \\
P2D3 & $25,40 \mathrm{~b}$ \\
\hline
\end{tabular}

Keterangan: Huruf kecil yang berbeda dalam kolom yang sama menunjukkan adanya perbedaan yang signifikan setelah diuji DMRT pada $p=0,05 . \mathrm{P} 1=$ pupuk kompos gulma siam, $\mathrm{P} 2$ = pupuk kompos komersial, $\mathrm{D} 0=$ penambahan bahan organik 0 $\%, \mathrm{D} 1=$ penambahan bahan organik $1 \%, \mathrm{D} 2$ = penambahan bahan organik $2 \%$, dan D3 = penambahan bahan organik $3 \%$.

Tabel 3. Jumlah daun tanaman dalam dua jenis kompos

\begin{tabular}{cc}
\hline Perlakuan & Jumlah daun (helai/tanaman) \\
\hline P1 & $25,00 \mathrm{~b}$ \\
P2 & $22,00 \mathrm{a}$ \\
\hline
\end{tabular}

Keterangan: Huruf kecil yang berbeda dalam kolom yang sama menunjukkan adanya perbedaan yang signifikan setelah diuji DMRT pada $p=0,05$. P1 $=$ pupuk kompos gulma siam dan $\mathrm{P} 2$ = pupuk kompos komersial.

\section{Tinggi Tanaman}

Tinggi tanaman selada dipengaruhi interaksi jenis pupuk kompos dan dosis pupuk kompos. Tabel 2. menunjukkan bahwa tinggi tanaman selada dipengaruhi interaksi jenis pupuk dan dosis pupuk kompos. Tinggi tanaman merupakan salah satu parameter pertumbuhan tanaman. Tanaman setiap waktu terus tumbuh, menunjukkan telah terjadi pembelahan dan 
pembesaran sel. Pertumbuhan tanaman sangat dipengaruhi faktor lingkungan, fisiologi dan genetika tanaman (Nurrohman et al., 2014). Marpaung (2017), menyatakan bahwa pemberian POC gulma siam meningkatkan pertumbuhan tanaman dimana pupuk organik mengandung unsur hara makro dan mikro yang diperlukan tanaman untuk pertumbuhannya. Pemberian kompos pada semua dosis meningkatkan tinggi tanaman. Penambahan 2-3\% bahan organik asal kompos gulma siam telah meningkatkan tinggi tanaman secara maksimal. Penggunaan pupuk gulma siam menjadi alternatif dalam meningkatkan pertumbuhan tanaman (Kadja, 2015).

\section{Jumlah Daun}

Jumlah daun tanaman selada dipengaruhi secara mandiri oleh jenis pupuk kompos dan dosis yang digunakan. Tabel 3. menunjukkan bahwa jumlah daun dipengaruhi oleh jenis pupuk gulma siam. Sesuai dengan penelitian Nugroho et al. (2019), kompos gulma siam meningkatkan pertumbuhan tanaman pada variabel jumlah daun, tinggi tanaman, bobot tanaman segar dan bobot tanaman kering.

Tabel 4. menunjukkan bahwa jumlah daun dipengaruhi oleh dosis pupuk yang diberikan. Penambahan 2-3 \% bahan organik mampu meningkatkan jumlah daun dengan optimal. Pemberian bahan organik memperbaiki sifat kimia dan sifat fisik tanah yang selanjutnya meningkatkan kemampuan tumbuh dan kemampuan produksi tanaman yang dibudidayakan (Inonu et al., 2014).

\section{Bobot Tanaman Segar (BTS)}

Tabel 5. menunjukkan bahwa bobot tanaman segar dipengaruhi oleh interaksi jenis kompos dengan dosis yang digunakan. Penggunaan kompos mampu menaikkan bobot tanaman segar. Kompos gulma siam dengan penambahan bahan organik 2-3\% memberikan bobot tinggi. Hal ini sejalan dengan pendapat (Nirmala, 2013), bahwa semakin tinggi dosis pupuk yang diberikan cenderung meningkatkan bobot tanaman segar selada. Samini \& Fatah (2020), menyatakan bahwa peningkatan bobot berat basah tanaman terjadi karena peningkatan ketersediaan unsur hara bagi tanaman, sehingga meningkatkan jumlah dan ukuran sel secara optimal.

Pemberian bahan organik mampu memperbaiki sifat fisik, kimia dan biologi tanah. Perbaikan sifat fisik tanah antara lain memperbaiki drainase, meningkatkan ikatan antar partikel tanah, meningkatkan kapasitas menahan air, dan memperbaiki daya olah tanah. Fungsi pupuk organik terhadap sifat kimia tanah meningkatkan kapasitas tukar kation, meningkatkan ketersediaan unsur hara, dan meningkatkan pelapukan bahan mineral. Bahan organik berpengaruh terhadap sifat biologi yaitu meningkatkan makanan bagi mikroba tanah 
Tabel 4. Jumlah daun dalam empat dosis

\begin{tabular}{cc}
\hline Perlakuan & Jumlah daun (helai/tanaman) \\
\hline D0 & $19,80 \mathrm{a}$ \\
D1 & $22,50 \mathrm{~b}$ \\
D2 & $26,50 \mathrm{c}$ \\
D3 & $27,00 \mathrm{c}$ \\
\hline
\end{tabular}

Keterangan: Huruf kecil yang berbeda dalam kolom yang sama menunjukkan adanya perbedaan yang signifikan setelah diuji DMRT pada $p=0,05$. D0 $=$ penambahan bahan organik $0 \%, \mathrm{D} 1=$ penambahan bahan organik $1 \%, \mathrm{D} 2=$ penambahan bahan organik $2 \%$, dan D3 = penambahan bahan organik $3 \%$.

Tabel 5. Bobot tanaman segar pada masing masing perlakuan

\begin{tabular}{|c|c|}
\hline Perlakuan & Bobot tanaman segar $(\mathrm{g})$ \\
\hline P1D0 & $7,00 \quad a b$ \\
\hline P1D1 & 19,57 \\
\hline P1D2 & $30,57 \mathrm{~d}$ \\
\hline P1D3 & $29,50 \quad d$ \\
\hline P2D0 & 6,67 \\
\hline P2D1 & $9,60 \quad a b c$ \\
\hline $\mathrm{P} 2 \mathrm{D} 2$ & $15,90 \quad \mathrm{bc}$ \\
\hline P2D3 & $20,09 \quad \mathrm{c}$ \\
\hline
\end{tabular}

Keterangan: Huruf kecil yang berbeda dalam kolom yang sama menunjukkan adanya perbedaan yang signifikan setelah diuji DMRT pada $p=0,05 . \mathrm{P} 1=$ pupuk kompos gulma siam, $\mathrm{P} 2$ = pupuk kompos komersial, $\mathrm{D} 0=$ penambahan bahan organik $0 \%$, $\mathrm{D} 1$ = penambahan bahan organik 1\%, D2 = penambahan bahan organik $2 \%$, dan D3 = penambahan bahan organik $3 \%$.

sehingga perkembangannya lebih cepat (Djufry \& Ramlan, 2013).

Semakin tinggi tanaman selada, maka jumlah buku yang dimiliki akan semakin banyak. Banyaknya buku mempengaruhi banyaknya jumlah daun, sehingga berpengaruh terhadap luas daun. Semakin luas daun maka tempat fotosintesis akan semakin banyak, sehingga memperoleh fotosintat yang semakin banyak, mengakibatkan bobot tanaman segar semakin tinggi (Manuhuttu et al., 2014).

Penggunaan kompos harus memperhatikan dosis. Semakin banyak dosisnya maka unsur hara yang diterima tanah akan semakin banyak. Pemberian unsur hara dapat menimbulkan kelayuan tanaman (Djufry \& Ramlan, 2013). Pada perlakuan kompos gulma siam dengan penambahan bahan organik 2-3\% mampu menghasilkan bobot segar selada lebih dari $29 \mathrm{~g}$.

\section{Bobot Tanaman Kering (BTK)}

Bobot tanaman kering dipengaruhi secara mandiri oleh jenis pupuk kompos dan dosis pupuk kompos. Tabel 6 . menunjukkan bahwa kompos gulma siam lebih baik dibandingkan dengan pembanding. Bobot kering penting karena erat hubungannya dengan besarnya hasil. 
Tabel 6. Bobot tanaman kering dalam dua jenis kompos

\begin{tabular}{|c|c|c|}
\hline \multicolumn{2}{|r|}{ Perlakuan } & Bobot tanaman kering $(\mathrm{g})$ \\
\hline & $\mathrm{P} 1$ & $3,51 \mathrm{~b}$ \\
\hline & $\mathrm{P} 2$ & $2,05 \mathrm{a}$ \\
\hline$\overline{\text { Keterangan: }}$ & $\begin{array}{l}\text { Huruf kecil y } \\
\text { perbedaan yan } \\
\text { kompos gulma }\end{array}$ & $\begin{array}{l}\text { yang sama menunjukkan adanya } \\
\text { MRT pada } p=0,05 . \mathrm{P} 1=\text { pupuk } \\
\text { s komersial. }\end{array}$ \\
\hline
\end{tabular}

Tabel 7. Bobot tanaman kering dalam empat dosis

\begin{tabular}{cc}
\hline Perlakuan & Bobot tanaman kering $(\mathrm{g})$ \\
\hline D0 & $0,89 \mathrm{a}$ \\
D1 & $2,31 \mathrm{~b}$ \\
D2 & $3,67 \mathrm{c}$ \\
D3 & $4,25 \mathrm{~d}$ \\
\hline
\end{tabular}

Keterangan: Huruf kecil yang berbeda dalam kolom yang sama menunjukkan adanya perbedaan yang signifikan setelah diuji DMRT pada $p=0,05$. D0 $=$ penambahan bahan organik $0 \%, \mathrm{D} 1=$ penambahan bahan organik $1 \%, \mathrm{D} 2=$ penambahan bahan organik $2 \%$, dan D3 = penambahan bahan organik $3 \%$.

Tabel 8. Bobot akar segar (g) dalam dua jenis kompos

\begin{tabular}{cc}
\hline Perlakuan & Bobot Akar Segar $(\mathrm{g})$ \\
\hline P1 & $2,12 \mathrm{~b}$ \\
P2 & $1,31 \mathrm{a}$ \\
\hline
\end{tabular}

Keterangan: Huruf kecil yang berbeda dalam kolom yang sama menunjukkan adanya perbedaan yang signifikan setelah diuji DMRT pada $p=0,05 . \mathrm{P} 1=$ pupuk kompos gulma siam dan $\mathrm{P} 2$ = pupuk kompos komersial.

Tinggi rendahnya berat kering tergantung dari banyak atau sedikitnya bahan kering dalam tanaman. Bahan kering tanaman terdiri dua macam bahan organik, yaitu bahan organik yang mengandung nitrogen tersusun oleh $\mathrm{C}, \mathrm{H}, \mathrm{O}$ dan $\mathrm{N}$, serta bahan organik yang tersusun oleh $\mathrm{C}, \mathrm{H}$ dan $\mathrm{O}$; sedangkan bahan mineral terdiri atas unsur hara selain $\mathrm{C}, \mathrm{H}, \mathrm{O}$ dan $\mathrm{N}$ (Noventa \& Triyono, 2015).

Tabel 7. menunjukkan semakin tinggi dosis yang digunakan, maka semakin tinggi berat tanaman kering. Berat tanaman kering yang besar menggambarkan kemampuan tanaman menghasilkan asimilat yang besar pula. Manuhuttu et al. (2014), menyatakan bahwa fotosintat yang terbentuk dengan baik dihasilkan oleh unsur hara yang cukup.

\section{Bobot Akar Segar (BAS)}

Bobot akar segar dipengaruhi secara mandiri oleh jenis kompos dan dosis yang digunakan. Tabel 8. menunjukkan bahwa penggunaan kompos gulma siam lebih baik dibandingkan dengan kompos pembanding. Pemberian kompos ke dalam tanah akan meningkatkan bahan organik tanah yang memicu kesuburan tanah. Pemberian pupuk kompos ke dalam tanah akan meningkatkan bahan organik tanah. Bahan organik mempunyai peranan penting sebagai bahan 
pemicu kesuburan tanah. Meningkatnya aktivitas biologi tanah akibat pemberian bahan organik akan mendorong terjadinya perbaikan kesuburan tanah, baik kesuburan fisik, kimia maupun biologi tanah. Perbaikan sifat fisik, kimia dan biologi tanah yang searah dengan kebutuhan tanaman akan mampu memperbaiki pertumbuhan dan produktivitas tanaman (Magdalena et al., 2013).

Tabel 9. menunjukkan bahwa semakin tinggi dosis yang digunakan semakin tinggi pula bobot akar segar. Pertumbuhan bobot akar segar yang baik Tabel 9. Bobot akar segar dalam empat dosis

\begin{tabular}{cc}
\hline Perlakuan & Bobot akar segar $(\mathrm{g})$ \\
\hline D0 & $0,77 \mathrm{a}$ \\
D1 & $1,63 \mathrm{~b}$ \\
D2 & $2,12 \mathrm{c}$ \\
D3 & $2,35 \mathrm{c}$ \\
\hline
\end{tabular}

Keterangan: Huruf kecil yang berbeda dalam kolom yang sama menunjukkan adanya perbedaan yang signifikan setelah diuji DMRT pada $p=0,05$. D0 $=$ penambahan bahan organik $0 \%, \mathrm{D} 1=$ penambahan bahan organik $1 \%$ ), $\mathrm{D} 2=$ penambahan bahan organik $2 \%$, dan D3 = penambahan bahan organik $3 \%$.

Tabel 10. Bobot akar kering pada masing masing perlakuan

\begin{tabular}{cc}
\hline Perlakuan & Bobot akar kering $(\mathrm{g})$ \\
\hline P1D0 & $0,03 \mathrm{a}$ \\
P1D1 & $0,07 \mathrm{bc}$ \\
P1D2 & $0,08 \mathrm{~d}$ \\
P1D3 & $0,08 \mathrm{~d}$ \\
P2D0 & $0,03 \mathrm{a}$ \\
P2D1 & $0,03 \mathrm{a}$ \\
P2D2 & $0,04 \mathrm{bc}$ \\
P2D3 & $0,05 \mathrm{c}$ \\
\hline
\end{tabular}

Keterangan: Huruf kecil yang berbeda dalam kolom yang sama menunjukkan adanya perbedaan yang signifikan setelah diuji DMRT pada $p=0,05 . \mathrm{P} 1=$ pupuk kompos gulma siam, $\mathrm{P} 2=$ pupuk kompos komersial, $\mathrm{D} 0=$ penambahan bahan organik $0 \%$, $\mathrm{D} 1=$ penambahan bahan organik 1\%, D2 = penambahan bahan organik $2 \%$, dan D3 = penambahan bahan organik $3 \%$. 
Tabel 11. Total panjang akar dalam dua jenis kompos

\begin{tabular}{cc}
\hline Perlakuan & Total panjang akar $(\mathrm{cm})$ \\
\hline P1 & $728,72 \mathrm{~b}$ \\
P2 & $548,09 \mathrm{a}$ \\
\hline
\end{tabular}

Keterangan: Huruf kecil yang berbeda dalam kolom yang sama menunjukkan adanya perbedaan yang signifikan setelah diuji DMRT pada $p=0,05$. P1 $=$ pupuk kompos gulma siam, dan P2 = pupuk kompos komersial

Tabel 12. Total panjang akar dalam empat dosis

\begin{tabular}{cc}
\hline Perlakuan & Total panjang akar $(\mathrm{g})$ \\
\hline D0 & $461,09 \mathrm{a}$ \\
D1 & $621,62 \mathrm{~b}$ \\
D2 & $738,46 \mathrm{c}$ \\
D3 & $804,46 \mathrm{~d}$ \\
\hline
\end{tabular}

Keterangan: Huruf kecil yang berbeda dalam kolom yang sama menunjukkan adanya perbedaan yang signifikan setelah diuji DMRT pada $p=0,05 . \mathrm{D} 1=$ penambahan bahan organik 1\%, D2 = penambahan bahan organik $2 \%$, dan D3 = penambahan bahan organik $3 \%$.

\section{Bobot Akar Kering (BAK)}

Tabel 10. menunjukkan bahwa bobot akar kering dipengaruhi oleh interaksi antara jenis pupuk dan dosis pupuk. Bobot kering tinggi dicapai pada perlakuan kompos gulma siam dengan penambahan bahan organik 2-3\%. Pemberian kompos mampu memperbaiki sifat biologi tanah. Sifat biologi tanah yang baik untuk pertumbuhan tanaman selada adalah tanah yang banyak mengandung bahan organik (humus) dan bermacam unsur hara yang berguna untuk pertumbuhan tanaman, serta pada tanah terdapat jasad renik tanah atau organisme tanah pengurai bahan organik, sehingga sifat biologi tanah yang baik akan meningkatkan pertumbuhan tanaman (Nasution et al., 2014).

\section{Total Panjang Akar}

Total panjang akar dipengaruhi secara mandiri oleh jenis pupuk dan dosis yang digunakan. Tabel 11. menunjukkan bahwa kompos gulma siam memiliki pengaruh yang lebih baik dibandingkan dengan kompos pembanding. Berdasarkan pengamatan kompos gulma siam secara deskriptif, kompos gulma siam memiliki tekstur yang lebih lunak dibandingkan dengan kompos pembanding, sehingga lebih mudah ditembus akar tanaman.

Tabel 12 menunjukkan bahwa semakin tinggi dosis yang digunakan, maka semakin tinggi pula total panjang akar yang diperoleh. Semakin panjang akar, maka semakin banyak unsur hara dan air yang diserap oleh tanaman. Pemberian pupuk kompos ke dalam tanah akan meningkatkan bahan organik tanah. Bahan organik mempunyai peranan penting sebagai bahan pemicu kesuburan tanah. Meningkatnya aktivitas biologi tanah akibat pemberian bahan organik akan mendorong terjadinya 
perbaikan kesuburan tanah, baik kesuburan fisik, kimia maupun biologi tanah. Perbaikan sifat fisik, kimia dan biologi tanah yang searah dengan kebutuhan tanaman akan mampu memperbaiki pertumbuhan dan produktivitas tanaman (Magdalena et al., 2013).

\section{Luas Daun}

Luas daun tanaman selada dipengaruhi oleh interaksi jenis pupuk dan dosis yang digunakan (Tabel 13). Luas daun tertinggi diperoleh pada penggunaan kompos gulma siam dengan dosis bahan organik 2-3\%. Aerasi tanah yang baik diperlukan dalam penyerapan unsur hara dan air. Pemberian pupuk kompos memperbaiki sifat fisik tanah, sehingga menunjang pertumbuhan tanaman. Luas daun yang tinggi menyebabkan fotosintesis berjalan dengan baik. Semakin luas daun suatu tanaman maka cahaya matahari yang diterima semakin banyak. Cahaya matahari merupakan sumber energi yang digunakan Tabel 13. Luas daun $\left(\mathrm{cm}^{2}\right)$ pada masing-masing perlakuan

\begin{tabular}{cc}
\hline Perlakuan & Luas daun $\left(\mathrm{cm}^{2}\right)$ \\
\hline P1D0 & 245,76 a \\
P1D1 & 550,91 cd \\
P1D2 & 811,77 e \\
P1D3 & 783,01 e \\
P2D0 & 248,34 a \\
P2D1 & 294,38 ab \\
P2D2 & 455,23 b \\
P2D3 & 589,58 d \\
\hline
\end{tabular}

Keterangan: Huruf kecil yang berbeda dalam kolom yang sama menunjukkan adanya perbedaan yang signifikan setelah diuji DMRT pada $p=0,05$. P1 $=$ pupuk kompos gulma siam, $\mathrm{P} 2$ = pupuk kompos komersial, $\mathrm{D} 0=$ penambahan bahan organik $0 \%$, $\mathrm{D} 1=$ penambahan bahan organik $1 \%, \mathrm{D} 2$ = penambahan bahan organik $2 \%$, dan D3 = penambahan bahan organik $3 \%$. untuk proses fotosintesis. Luas daun yang tinggi, maka cahaya mudah diterima oleh daun dengan baik (Nurrohman et al., 2014).

\section{Laju Asimilasi Bersih}

Laju asimilasi bersih tanaman selada dipengaruhi oleh dosis pupuk kompos yang digunakan. Tabel 14 menunjukkan bahwa semakin tinggi dosis yang digunakan maka semakin tinggi laju asimilasinya. Penambahan bahan organik 2-3\% menunjukkan laju yang tinggi dibandingkan dosis lainnya. Peningkatan nitrogen dalam tanah mengakibatkan pertumbuhan tanaman selada semakin cepat, sehingga mempengaruhi laju asimilasi bersihnya. Nitrogen merupakan unsur hara makro yang berguna sebagai penyusun protein, enzim, hormon dan klorofil (Andreeilee et al., 2014). Penambahan bahan organik 2-3\% meningkatkan luas daun tanaman yang efektif meningkatkan laju asimilasi bersih. 
Tabel 14. Laju asimilasi bersih dalam empat dosis

\begin{tabular}{cc}
\hline Perlakuan & Laju asimilasi bersih $\left(\mathrm{g} / \mathrm{cm}^{2} / \mathrm{hari}\right)$ \\
\hline D0 & $7,59 \times 10^{-4}$ \\
D1 & $12.33 \times 10^{-4}$ \\
D2 & $13.77 \times 10^{-4}$ \\
D3 & $48.56 \times 10^{-4}$ \\
\hline
\end{tabular}

Keterangan: Huruf kecil yang berbeda dalam kolom yang sama menunjukkan adanya perbedaan yang signifikan setelah diuji DMRT pada $p=0,05 . \mathrm{D} 0=$ penambahan bahan organik $0 \%, \mathrm{D} 1=$ penambahan bahan organik $1 \%, \mathrm{D} 2=$ penambahan bahan organik $2 \%$, dan D3 = penambahan bahan organik $3 \%$.

Tabel 15. Laju pertumbuhan tanaman dalam dua jenis kompos

\begin{tabular}{cc}
\hline Perlakuan & Laju pertumbuhan tanaman \\
\hline P1 & $4,27 \mathrm{~b}$ \\
P2 & $2,54 \mathrm{a}$ \\
\hline
\end{tabular}

Keterangan: Huruf kecil yang berbeda dalam kolom yang sama menunjukkan adanya perbedaan yang signifikan setelah diuji DMRT pada $p=0,05 . \mathrm{P} 1=$ pupuk kompos gulma siam, dan P2 = pupuk kompos komersial.

Tabel 16. Laju pertumbuhan tanaman dalam empat dosis

\begin{tabular}{cc}
\hline Perlakuan & Laju pertumbuhan tanaman \\
\hline D0 & $1,15 \mathrm{a}$ \\
D1 & $2,77 \mathrm{~b}$ \\
D2 & $4,51 \mathrm{c}$ \\
D3 & $5,19 \mathrm{~d}$ \\
\hline
\end{tabular}

Keterangan: Huruf kecil yang berbeda dalam kolom yang sama menunjukkan adanya perbedaan yang signifikan setelah diuji DMRT pada $p=0,05$. D0 $=$ penambahan bahan organik $0 \%, \mathrm{D} 1=$ penambahan bahan organik $1 \%, \mathrm{D} 2=$ penambahan bahan organik $2 \%$, dan D3 = penambahan bahan organik $3 \%$.

\section{Laju Asimilasi Bersih}

Laju asimilasi bersih tanaman selada dipengaruhi oleh dosis pupuk kompos yang digunakan. Tabel 14 menunjukkan bahwa semakin tinggi dosis yang digunakan maka semakin tinggi laju asimilasinya. Penambahan bahan organik $3 \%$ menunjukkan laju yang tinggi dibandingkan dosis lainnya. Semakin tinggi dosis bahan organik yang diberikan, maka akan meningkatkan kandungan $\mathrm{N}$ yang diberikan ke tanaman. Peningkatan nitrogen dalam tanah mengakibatkan pertumbuhan tanaman selada semakin cepat, sehingga mempengaruhi laju asimilasi bersihnya. Nitrogen merupakan unsur hara makro yang berguna sebagai penyusun protein, enzim, hormon dan klorofil (Andreeilee et al., 2014). Penambahan bahan organik 2-3\% meningkatkan luas daun tanaman yang efektif meningkatkan laju asimilasi bersih.

\section{Laju Pertumbuhan Tanaman}

Laju pertumbuhan tanaman dipengaruhi oleh jenis kompos (Tabel 15) dan dosis yang digunakan (Tabel 16). Kompos gulma siam memiliki laju yang 
lebih tinggi dibandingkan dengan kompos pembanding. Semakin tinggi dosis yang digunakan laju pertumbuhan akan semakin tinggi. Laju pertumbuhan tanaman merupakan gambaran kapasitas tanaman untuk menambahkan bahan kering pada periode tertentu dari setiap bahan kering yang dihasilkan. Bahan kering merupakan ukuran yang menggambarkan pertumbuhan tanaman atau organ tertentu (Rochman et al., 2017).

Tabel 16. menunjukkan bahwa semakin tinggi dosis yang digunakan akan menaikkan laju pertumbuhan tanaman. Pertumbuhan dan hasil sangat dipengaruhi oleh penyerapan unsur hara yang dilepaskan bahan organik. Hal tersebut terkait kesesuaian menurut waktu antara laju pelepasan suatu unsur hara dalam bentuk tersedia bagi tanaman dengan laju kebutuhan tanaman akan unsur hara tersebut. Kesesuaian tersebut ditentukan oleh kecepatan pengomposan dan pemineralan (pelepasan unsur hara) bahan organik. Tanggapan tanaman terhadap keterbatasan jumlah unsur hara tersedia berhubungan dengan faktor pembatas yang menentukan pertumbuhan dan hasil tanaman (Nurrohman et al., 2014).

\section{KESIMPULAN}

Aplikasi pupuk kompos komersial atau pupuk kompos gulma siam mampu meningkatkan pertumbuhan tanaman selada dan mampu meningkatkan hasil segar tanaman apabila ditambahkan bahan organik $2-3 \%$.

\section{DAFTAR PUSTAKA}

Andreeilee, B. F., Santoso, M., \& Nugroho, A. (2014). Pengaruh jenis kompos kotoran ternak dan waktu penyiangan terhadap produksi tanaman pakcoy (Brassica rapa Sub. Chienensis) organik. Jurnal Produksi Tanaman, 2(3), 190-197.

Berek, A. K., Ceunfin, S., Taolin, R. I. C., Neonbeni, E. Y., \& Seran, M. J. (2017). Efek biochar dan teh kompos terhadap pertumbuhan dan hasil selada darat (Lactuca sativa $\mathrm{L}$ ) di tanah vertisol semiarid. Jurnal Floratek, 12(2), 101-114.

Djufry, F., \& Ramlan. (2013). Uji efektivitas pupuk organik cair plus hi-tech 19 pada tanaman sawi hijau di Sulsel. In Seminar Nasional Inovasi Teknologi Pertanian (pp. 408-416). http://kalsel.litbang.perta nian.go.id > prosiding.

Fauzi, R., Putra, E. T. S., \& Ambarwati, E. (2013). Pengayaan oksigen di zona perakaran untuk meningkatkan pertumbuhan dan hasil selada (Lactuca sativa L.) secara hidroponik. Vegetalika, 2(4), 63-74.

Febriyono, W., Soesanto, L., \& Tamad. (2018). Potensi Trichoderma sp. dalam pengomposan gulma siam dan pengaruhnya terhadap hasil tanaman pakcoi dan sifat kimia tanah ultisol. Jurnal Ilmiah Media Agrosains, 4(1), 48-54.

Hartini. (2020). Eksplorasi potensi gulma siam (Chromolaena odorata) sebagai kompos dan jamur mikoriza arbuskular (JMA) terhadap pertumbuhan bibit kakao. Jurnal Ilmiah Media Agrosains, 6(1), 7-13. 
Inonu, I., Khodijah, N., \& Supriadi, A. (2014). Budidaya pakchoy (Brassica rapa $\mathrm{L}$.) di lahan tailing pasir bekas penambangan timah dengan amelioran pupuk organik dan pupuk NPK. Jurnal Lahan Suboptimal, 3(1), 76-82.

Ismangil. 2009. Potensi Batu Beku, Kalsit dan Campuranya Sebagai Amelioran Pada Bahan Tanah Lempung Aktivitas Rendah. Disertasi. Progam Pasca Sarjana Universitas Gajah Mada. Yogyakarta. (Tidak dipublikasi).

Kadja, D. H. (2015). Pengaruh jenis pupuk dan tinggi genangan air terhadap perkembangan populasi wereng batang padi cokelat pada tanaman padi. Ilmu Pertanian, 18(1), 18-23. https://doi.org/10.22146/ipas.6171

Magdalena, F., Sudiarso, \& Sumarni, T. (2013). Penggunaan pupuk kandang dan pupuk hijau Crotalaria juncea L. untuk mengurangi penggunaan pupuk anorganik pada tanaman jagung (Zea mays L.). Jurnal Produksi Tanaman, 1(2), 61-71.

Manuhuttu, A. P., Rehatta, H., \& Kailola, J. J. (2014). Pengaruh konsentrasi pupuk hayati bioboost terhadap peningkatan produksi tanaman selada (Lactuca sativa. L). Agrologia, 3(1), 18-27. http://dx.doi.org/10.30598/a. v3i1.256

Marpaung, A. E. (2017). Pemanfaatan jenis dan dosis pupuk organik cair (POC) untuk meningkatkan pertumbuhan dan hasil sayuran kubis. Jurnal Agroteknosains, 01(2), 117-123.

Nasution, F. J., Mawarni, L., \& Meiriani. (2014). Aplikasi pupuk organik padat dan cair dari kulit pisang kepok untuk pertumbuhan dan produksi sawi (Brassica juncea L.). Jurnal Online Agroekoteknologi, 2(3), 1029-1037.

Nirmala, R. (2013). Pengaruh konsentrasi puuk organik cair kosarine terhadap prtumbuhan dan hasil tanaman selada. Agrin, 17(2), 113-121.

Noventa, O. C., \& Triyono, K. (2015). Pengaruh konsentrasi EM4 dan limbah media tanam jamur tiram terhadap intensitas penyakit becak daun alternaria pada tanaman pakchoy (Brassica rapa L). Jurnal Inovasi Pertanian, 14(1), 68-77.

Nugroho, B., Mildaryani, W., \& Dewi, S. H. C. (2019). Potensi gulma siam (Chromolaena odorata L .) sebagai bahan kompos untuk pengembangan bawang merah organik. Jurnal Agronomi Indonesia, 47(2), 180-187. https://doi.org/10.24831/jai.v47i2.23 $\underline{440}$

Nurrohman, M., Suryanto, A., \& W, K. P. (2014). Penggunaan fermentasi ekstrak paitan (Tithonia diversifolia L.) dan kotoran kelinci cair sebagai sumber hara pada budidaya sawi (Brassica juncea L.) Secara Hidroponik Rakit Apung. Jurnal Produksi Tanaman, 2(8), 649-657.

Rochman, A. S., Suryanto, A., \& Sugito, Y. (2017). Pengaruh dosis pupuk kandang dan varietas pada hasil tanaman brokoli (Brassica oleracea L. Var . Italica). Jurnal Produksi Tanaman, 5(8), 1250-1256.

Sahwan, F. L. (2010). Pengaruh penambahan starter terhadap karakteristik proses pengomposan dan kualitas kompos limbah pabrik agar. Jurnal Teknologi Lingkungan, 11(2), 247-253. https://doi.org /10.29122/jtl.v11i2.1209

Samini, \& Fatah, A. (2020). Pengaruh pupuk urea dan pupuk kompos terhadap pertumbuhan dan hasil tanaman sawi (Brassica juncea L.). Jurnal Agrifor, 19(1), 163-166. https://doi.org/10.31293/af.v19i1.462 $\underline{4}$

Sitompul, S. M., \& Guritno, B. (1995). Analisis Pertumbuhan Tanaman. 
Yogyakarta: Gadjah Mada University Press.

Suharjo, R., \& Aeny, T. N. (2011). Eksplorasi potensi gulma siam (Chromolaena odorata) sebagai biofungisida pengendali Phytophthora palmivora yang diisolasi dari buah kakao. Jurnal Hama dan Penyakit Tumbuhan Tropika, 11(2), 201-209.

https://doi.org/10.23960/j.hptt.21120

\section{$\underline{1-209}$}

Sujana, I. P., \& Pura, I. N. L. S. (2015). Pengelolaan tanah ultisol dengan pemberian pembenah organik biochar menuju pertanian berkelanjutan. Agrimerta, 5(9), 1-9.

Syahputra, E., Fauzi, \& Razali. (2015). Karakteristik sifat kimia sub grup tanah ultisol di beberapa wilayah Sumatera Utara. Jurnal Agroekoteknologi, 4(1), 1796-1803. 